\title{
Inter-Firm Technology Transfer and Performance in International Joint Venture Firms
}

\author{
Sazali Abdul Wahab \\ Graduate School of Management, Universiti Putra Malaysia \\ 43400 Selangor, Malaysia \\ E-mail: saw639@gmail.com
}

Haslinda Abdullah

Faculty of Economics \& Management, Universiti Putra Malaysia

43400 Selangor, Malaysia

Tel: 603-8946-7638Ｅ-mail: hba@putra.upm.edu.my

Jegak Uli

Faculty of Educational Studies, Universiti Putra Malaysia

43400 Selangor, Malaysia

E-mail: jegak@ace.upm.edu.my

Raduan Che Rose

Faculty of Economics \& Management, Universiti Putra Malaysia

43400 Selangor, Malaysia

E-mail: rcr@putra.upm.edu.my

\begin{abstract}
The main objective of this paper is to empirically examine the effects of two distinct degrees of technology transfer: degree of tacit and explicit knowledge on two dimensions of performance: corporate and human resource performances. Using the quantitative analytical approach, the theoretical model and hypotheses in this study were tested based on empirical data gathered from 128 joint venture companies registered with the Registrar of Companies of Malaysia (ROC). Data obtained from the survey questionnaires were analyzed using the correlation coefficients and multiple linear regressions. The results revealed that degree of tacit knowledge, as a distinct dimension of degree of technology transfer, has a significant effect on both corporate and human resource performances; where its effect was much stronger on corporate performance. Similarly, degree of explicit knowledge has shown consistent strong significant effects on both corporate and human resource performance; where its effect on human resource performance was found much stronger than corporate performance. The study has bridged the literature gaps in such that it offers empirical evidence on the effects of two distinct degrees of technology transfer: degrees of tacit and explicit knowledge on two dimensions of performance: corporate and human resource performances in IJVs.
\end{abstract}

Keywords: Inter-Firm, Technology transfer, International joint ventures, Local firms' performance, Malaysia

\section{Introduction}

In the context of developing country, technology is viewed as an important catalyst of corporate success and national economic growth (Millman, 2001). Due to lack of resource capacities such as a weak research and development ( $\mathrm{R} \& \mathrm{D})$ base, limited investment in $\mathrm{R} \& \mathrm{D}$, production and manufacturing capability, weak infrastructure and technological disadvantage (Lado and Vozikis, 1996; Tepstra and David, 1985), Malaysia like other developing countries, mainly depends on the multinational corporations (MNCs) as its primary source of technology to enhance the technological capabilities and competitiveness of local industries (Lee and Tan, 2006). This is because MNCs own, produce and control the bulk of world technology in which they undertake nearly 
$80 \%$ of all private R\&D expenditures worldwide (Dunning, 1993). Past studies have acknowledged the important role of MNCs as the main source of technology; where MNCs are regarded as the most efficient vehicle for transferring technology and knowledge across borders especially through international joint ventures (IJVs), (Tihanyi and Roath, 2002; Kagut and Zander, 1993).

When compared to various forms of strategic alliance such as distribution and supply agreements, research and development partnerships or technical and management contract, IJVs are considered as the most efficient formal mechanism for technology transfer (TT) to occur through inter-partner learning between foreign MNCs and local firms (Kogut and Zander, 1993; Inkpen 1998a, 2000). IJVs are also viewed as the most efficient mode to transfer technology or knowledge which is organizationally embedded and difficult to transfer through licensing agreements (Kogut, 1988; Mowery, Oxley and Silverman, 1996). This is because IJVs provide both MNCs and local partners an appropriate avenue to facilitate the transfer of organizational knowledge, particularly for knowledge which is hard to be transferred without the setting up of a JV, such as institutional and cultural knowledge (Harrigan, 1984). Since JVs is one of the formal and externalized mechanisms of TT which could directly affect performance, therefore the next intriguing issue is on the extent of degree of technology transfer (TTDEG) in affecting the performance of local firms; specifically on how TTDEG could have influenced the corporate and human resource/competencies performance of local firms. Thus, based on the underlying knowledge-based view (KBV) and organizational learning (OL) perspectives, this study expects to fill in the gap in the existing inter-firm TT literature by empirically examining the effects of two distinct degrees of technology transfer: degrees of tacit (TCTDEG) and explicit (EXPDEG) on two dimensions of local firms' performance (LFP): corporate and human resource performances using data generated from joint venture companies formed in Malaysia.

\section{Technology Transfer}

The current TT issue in IJVs revolves around the extent of degree of technologies that are transferred (TTDEG) by the suppliers to recipient partners (Pak and Park, 2004; Minbaeva, 2007). The question is no longer whether or not the MNCs are transferring technology to local firms instead the focus in the literature has shifted to questions on 1) the level (sophistication) of the transferred technology, and 2) the stage where the transfer process has reached (Lai and Narayanan, 1997; Narayanan and Lai, 2000). Except for Pak and Park (2004) and Minbaeva (2007), not many studies in both intra and inter-firm TT have focused on TTDEG as independent or dependent variable. In general, majority of the studies have focused more on technological knowledge and knowledge acquisition 'per se' as the outcomes (dependant variables). For example, the technology transfer, knowledge transfer (KT) and strategic alliance literature have extensively examined the relationships between 1) knowledge attributes, source and recipient and KT success (Cummings et al., 2003), 2) knowledge seekers, knowledge holder and contextual factors and know-how acquisition (Hau and Evangelista, 2007), 3) IJVs characteristics and knowledge acquisition (Lyles and Salk, 1996), 4) knowledge actors' interaction and KT (Bresman et al., 1999), 5) organization motivation, learning capacity, learning hindrance and KT (Simonin, 2004), 6) absorptive capacity and knowledge learned from foreign firm (Lane et al., 2001), 7) the IJV characteristics and knowledge acquisition (Tsang et al., 2004), 8) knowledge antecedents, ambiguity and knowledge transfer (Simonin, 1999a), 9) learning intent, management control and managerial knowledge acquisition (Lin, 2005), 10) relational embeddedness and tacit/explicit knowledge acquisition (Dhanaraj et al., 2004), 11) overseeing effort, management involvement and knowledge acquisition (Tsang et al., 2002), 12) the supplier and recipient factors and tacit knowledge acquisition (Yin and Bao, 2006), and 13) relation-specific determinants, knowledge specific determinants and degree of knowledge transfer (Pak and Park, 2004).

Although the previous researchers have not specifically dealt with TTDEG as a variable, however, a number of studies have operationalized degree (amount) of technology transferred to the recipient firm in terms of the extent of type of technology and knowledge that are transferred or acquired for example 1) the tacit and explicit marketing knowledge (Hau and Evangalista, 2007), 2) the tacit and explicit knowledge (Dhanaraj et al., 2004; Yin and Bao, 2006), 3) the marketing know-how (Simonin, 1999b; Wong et al., 2002), 4) the technology in service industries (Grosse, 1996), 5) the knowledge on product development and foreign cultures (Lyles and Salk, 1996), 7) the technological learning (Lin, 2007), 8) the managerial knowledge (Si and Bruton, 1999; Tsang 2001; Luo and Peng, 1999; Liu and Vince, 1999; Lin, 2005), 9) managerial skills (Wong et al., 2002), 10) the technology or manufacturing know how (Lam, 1997; Bresman et al., 1999), 11) the business environment and product market knowledge (Geppert and Clark, 2003), and 12) the research and development (Cummings and Teng, 2003; Minbaeva, 2007). In the context of inter-firm technological knowledge transfer in IJVs, only Pak and Park (2004) have directly dealt with degree of knowledge transfer as the outcome (dependent variable) with respect to the transfer of new product development and manufacturing skills/techniques. 


\section{Theory and Hypotheses: Degree of Technology Transfer and Local Firms’ Performance}

A review of the literature indicates that previous researchers have broadly categorized technology in terms of its 'tacit' and 'explicit' nature (Polanyi, 1962). These two forms of technology are also referred to as 'hardware' and 'software' technology. The technology term has been extensively debated by both hardware and software schools. Based on the definitions given, the researchers from the hardware school define technology as "the construction and use of machines, systems, processes or engineering" (Strassman, 1968; Jones, 1970; Hawthorne, 1971; Galbraith, 1972; Goulet, 1989; Lovell, 1998; Reisman, 2005). Generally, hardware technology corresponds with explicit knowledge; which refers to knowledge which underlies technology that can easily be codified, shared, transmitted, retrieved, reused, transferable in formal or systematic language i.e. production manuals, academic papers, books, technical specifications, and designs, and is only useful when tacit knowledge enables individuals and organizations to use it (Techakanont and Terdudomtham, 2004). Software technology, on the other hand, corresponds with implicit/tacit knowledge underlying technology that is difficult to codify, communicate, transfer, and is generally exchanged through action, commitments and direct involvement such as face-to-face communication or on-the-job/apprenticeship type of training (Ernst and Kim, 2002).

The KBV studies have argued that tacit knowledge, which includes insights, intuitions, hunches, rule of thumb, gut feeling, personal and organizational skills, and managerial and marketing expertise, is difficult to codify; where it can only be observed through its application and acquired through practice (Nonaka, 1994; Lane et al., 2001). Thus, tacit knowledge transfer between individuals is slow, costly and uncertain (Kogut and Zander, 1992). Acquiring tacit knowledge is subject to time-compression diseconomies; which means to accelerate tacit knowledge learning is very difficult or perhaps not even possible no matter how much efforts or resources are invested to acquire them within a short period of time (Dierickx and Cool, 1989; Lin, 2003). This is because tacit knowledge is unique to the knowledge owner and not codifiable in formulas or manuals, and cannot be easily reverse-engineered (Zander and Kogut, 1995). On the other hand, explicit knowledge such as product technologies, physical distribution methods, and promotion techniques, lies in the organization's policies, systems, guidelines and standardized procedures, and could be acquired, exploited and transferred inter-organizationally in a formal and systematic language (Polanyi, 1967; Nelson and Winter, 1982; Martin and Solomon, 2003). Explicit knowledge is referred to as "knowledge that could be articulated, codified, shared and transferred in the form of data, formulae and principles, accessed using verbal communication and written documents through words and numbers, and is less likely to act as a firm's competitive advantage" (Kogut and Zander, 1992; Winter, 1987).

Other theoretical studies have argued that tacit knowledge is hard to formalize, often sticky, not easily visible, and difficult to communicate, transfer and share between the alliance partners as it involves 1) intangible factors embedded in the personal beliefs, experiences, and values in an organization (Inkpen, 1998a, 2000), 2) internal individual processes like experience, reflection, internalization or individual talents (Nonaka, 1994), and 3) high incremental cost of transferring knowledge to a specified location in a form usable by a given party (von Hippel, 1994). The OL literature theoretically deals with organization tacit knowledge from several dimensions for instance: 1) tacit knowledge as an important key in building the organization's competitiveness (Inkpen, 1998a), 2) organizational learning mainly occurs through transfer of tacit knowledge (Glaister et al. 2003), 3) organization capabilities often involve the acquisition of tacit knowledge (Makhija and Ganesh, 1997), 4) learning in $\mathrm{JV}$ is concentrated on the acquisition of tacit knowledge such as management skills and marketing know-how knowledge (Lane et al. 2001), and 5) knowledge tacitness determines the accessibility of alliance knowledge acquisition by partners (Inkpen, 2000).

The TT and KT literature have also acknowledge that a substantial transfer of technology regardless whether tacit or explicit technology will positively 1) lead to a higher potentials of innovation performance/capabilities (Guan et al., 2006; Kotabe et al., 2007)), 2) increase in technological capabilities (Kumar et al., 1999; Madanmohan et al., 2004), 3) enhance the competitive advantage (Liao and Hu, 2007; Rodriguez and Rodriguez, 2005), 4) enhance the organizational learning effectiveness (Inkpen, 2000; Inkpen and Dinur, 1998), 5) effect the productivity (Caves, 1974; Xu, 2000; Liu and Wang, 2003), 6) increase the technological development of local industry (Markusen and Venables, 1999), and 7) improve the economic growth of the host country (Blomstrom, 1990).

Most of the studies on strategic alliance operationalize performance as either the JV's or MNCs' subsidiary performance. A review of literature reveals that most of the empirical studies on inter-firm technology and knowledge transfer in strategic alliance, particularly on IJVs, are limiting their focus on the performance of the IJVs (Lyles and Salk, 1996; Lane et al., 2001; Tsang et al., 2004; Dhanaraj et al., 2004; Steensma and Lyles, 2000). In the context of intra-firm knowledge transfer many studies concentrate on the performance of the 
MNCs' subsidiary in the host countries (Chen, 1996; Chung, 2001; Ofer \& Potterovich, 2000, Cui et al., 2006; Lin, 2003). Intra and inter-firm empirical studies on knowledge transfer and acquisition have established that knowledge transfer and acquisition have a significant positive effect on human resource, business and general performance (Lyles and Salk, 1996), operational cost, operational efficiency, employee productivity, business volume, market share, market penetration, product quality, customer service, and customer satisfaction (Lane et al., 2001; Tsang et al., 2004; Dhanaraj et al., 2004; Cui et al., 2006). On the local firms' performance (LFP), tacit knowledge acquisition is found to have a significant positive effect on the recipient firms' performance in terms of increasing their productivity, revenue and market share (Yin and Bao, 2006). Based on the empirical studies, this study proposes the following hypotheses:

H1: Degree of tacit and explicit knowledge in inter-firm technology transfer is positively related to a higher degree of local firms' corporate performance.

H2: Degree of tacit and explicit knowledge in inter-firm technology transfer is positively related to a higher degree of local firms' human resources performance.

\section{Methods}

\subsection{Sample}

The sample frame was taken from the IJV companies registered with the Registrar of Companies (ROC). As at $1^{\text {st }}$ January 2008, the number of IJVs operating in Malaysia was 1038. Out of this, 850 IJVs were considered as active IJVs and 103 IJVs were either dormant or had ceased operation. Since the focus of this study is on inter-firm TT from foreign MNCs to local companies, $85 \mathrm{IJVs}$ were further eliminated from the population frame because only IJVs that have operated more than 2 years and have at least twenty percent (20\%) of foreign equity are eligible to participate in the survey. Therefore, based on the list provided by ROC, which is considered as the most official and original source of information on foreign investment in Malaysia, it was decided that all IJVs (850) be included in the survey. Data collection was conducted in the period from July 2008 to December 2008 using a self-administered questionnaire. The questionnaires were mailed to 850 active JV companies as listed with ROC using a cover letter. After one month from the posting date the response was found not encouraging. By mid July 2008 there were only 70 responses received from the respondents. Thus, in order to increase the response rate the researcher followed-up through numerous phone calls, e-mails, reminders via letters and personal visits to seek the respondents' cooperation in the survey. After intensive efforts were made, by mid November 2008 a total of 145 responses $(17.05 \%)$ were received. Based on literature review, the response rates for mailed questionnaires are usually not encouraging and low (Sekaran, 2003). In the Malaysian context, however, a response rate of $15 \%$ to $25 \%$ is still being considered appropriate and acceptable (Rozhan, Rohayu and Rasidah, 2001). From 145 responses only 128 questionnaires were usable and 17 questionnaires were returned blank, returned incomplete, or replied but unable to participate in the study.

\subsection{Instrument and measurement}

The main research instrument in this study is the questionnaire. Building on the previous KT and TT studies, the questionnaire adopts a multi-item scales which have been modified accordingly to suit the context of the study: inter-firm TT. Except for degree of technology transfer (TTDEG), all the variables are measured using ten-point Likert Scale $(1=$ strongly disagree to $10=$ strongly agree $)$. For TTDEG, this variable is measured using ten-point Likert Scale $(1=$ very low transfer to $10=$ substantial transfer $)$. The ten-point Likert Scale was selected because 1) the wider distribution of scores around the mean provides more discriminating power, 2) it is easy to establish covariance between two variables with greater dispersion around their means, 3) it has been well established in academic and industry research, and 4) from a model development perspective, a ten-point scale is more preferred (Allen and Rao, 2000).

\subsection{Dependent Variable - Local Firms' Performance (TTDEG)}

This study operationalizes LFP from two dimensions of performances: 1) corporate performance (CPERF), and 2) human resource (competencies) performance (HRPERF). Based on literature review, the qualitative (objective) measures of companies' performance are the most practical and ideal measurement of performance. However, the concrete financial figures are neither available nor reliable (Lyles and Barden, 2000; Tsang et al., 2004). Past studies have shown a positive relationship between objective and perceptual (subjective) measures of firm's performance (Lyles and Salk, 1996; Dess and Robinson, 1984; Geringer and Hebert, 1989, 1991). Thus, this study applies subjective measures to measure LFP based on IJV's top management assessments using "a multi-dimensional performance indicators". The CPERF, as the first dimension of LFP, is measured by a four (4) items scale measuring business volume, market share, planned goals and profits. For HRPERF, as the second 
dimension of LFP, four (4) items are used to measure product/service quality, employees' productivity, managerial techniques/skills and operational efficiency (Tsang et al., 2004; Yin and Bao, 2006; Lane et al., 2001; Lyles and Salk, 1996). The Cronbach Alphas for CPERF and HRPERF were 0.926 and 0.97 respectively. The results of Cronbach Alpha were well above of Lyles and Salk (1996).

\subsection{Independent Variables - Degree of Technology Transfer (TTDEG)}

Following Lyles and Salk (1996), Lane et al. (2001), Gupta and Govindarajan (2000), Dhanaraj et al. (2004), Pak and Park (2004), Yin and Boa (2006) and Minbaeva (2007), this study adopts "a multi-dimensional operationalization approach" in measuring this construct. This study operationalizes TTDEG as the transfer of technological knowledge in terms of two dimensions: 1) tacit knowledge (TCTDEG) in terms of new product/service development, managerial systems and practice, process designs and new marketing expertise, and 2) explicit knowledge (EXPDEG) in terms of manufacturing/service techniques/skills, promotion techniques/skills, distribution know-how, and purchasing know-how. The respondents are asked to evaluate TTDEG from MNCs to local firms in terms of tacit and explicit dimensions of technological knowledge. The Cronbach Alphas for TCTDEG and EXPDEG were 0.96 and 0.97 respectively. The results of Cronbach Alpha were quite similar to that of Hau and Evangelista (2007) and Yin and Bao (2006).

\section{Results}

As indicated in Table 1, there are clearly some associations between independent variables. For all the variables, it was found that there was no multicollinearity problem; where the T values were ranged between $0.442-0.444$ and the VIF values were between 2.262 - 2.377. Both degrees of tacit (TCTDEG) and explicit (EXPDEG) knowledge were strongly correlated with corporate performance (CPERF) $(p<0.01)$. It is also noted that TCTDEG and EXPDEG had positive signs indicating consistency with the theoretical arguments in the literature. The correlation results also indicated that both TCTDEG and EXPDEG had recorded strong correlations with HRPERF $(p<0.01)$.

Using multiple regression analysis, the effects of TCTDEG and EXPDEG on two dimensions of performance (CPERF and HRPERF) were estimated. As shown in Table 2 below, TCTDEG as a critical component of degree of technology transfer had significant effect on both corporate and human resource performances in inter-firm TT. The regression results indicated that TCTDEG in Model 1 had a stronger positive significant effect on corporate performance $(p<0.001$, Beta value $=0.485)$ as compared to its effect on human resource performance in Model $2(p<0.05$, Beta value $=0.196)$. This was also evident by the results of the adjusted $R$-squared in Model 1 and Model 2 ( 0.452 and 0.557 respectively) and the $F$ statistics (53.309 and 80.836 respectively). On the corresponding $p$ values, both results were statistically significance $(p=0.001)$. From the regression results $H 1$ is supported thus indicating that greater degrees of tacit and explicit knowledge transfer significantly contributes to a higher corporate and human resource performance in inter-firm TT through IJVs. Interestingly, the effect of TCTDEG on corporate performance is stronger than its effect on HRPERF. The finding suggests that technological knowledge on new product/service development, managerial systems and practices, process designs and new marketing expertises which are more tacit, complex and firm-specific could significantly generate a higher degree of corporate performance specifically the business volume, market share, planned goals and profits.

Consistent with the study's prediction, EXPDEG which has strong theoretical foundation showed a similar strong significant effects on both corporate and human resource performances $(p<0.01$ and $p<0.001$ respectively). As compared to the effect of EXPDEG on CPERF $(p<0.01)$ in Model 1, EXPDEG recorded an impressive stronger and better effect on HRPERF in Model $2(p<0.001)$ indicating a higher degree of explicit knowledge will likely to enhance more and better human resource performance as compared to corporate performance. This suggests that technological knowledge on product/service quality, employees' productivity, managerial techniques/skills and operational efficiency; which are less tacit, easier to articulate, and transferrable are more likely to generate a higher degree of human resource performance specifically the product/service quality, employees' productivity, managerial techniques/skills and operational efficiency. Thus, based on the two regression results for Model 1 and Model 2 above, $H 2$ is supported.

\section{Discussion and Conclusion}

Building on the underlying KBV and OL perspectives, this study has bridged the literature gaps by providing empirical evidence on the effects of two distinct degrees of technology transfer: degrees of tacit and explicit knowledge on two dimensions of performance: corporate and human resource performances using the Malaysia sample. The results suggest that the higher the degree of technology transfer (both tacit and explicit knowledge) the greater the corporate and human resource performance of local recipient firms. The results are consistent 
with the findings in the previous literature which found that both tacit (TCTDEG) and explicit (EXPDEG) knowledge are highly capable in increasing both performances (Lane et al., 2001; Lyles and Salk, 1996; Yin and Bao, 2006; Tsang et al., 2004) suggesting that a higher degree of TCTDEG and EXPDEG contributes to high improvement and increment of 1) the local firms' business volume, market share, planned goals, and profit, and 2) the local firms' product/service quality, employees' productivity, managerial techniques/skills, and operational efficiency (Dhanaraj et al., 2004). Interestingly, the results for significant effect of TCTDEG on CPERF have indeed supported the theoretical argument which argued that since tacit knowledge (new product/service development, managerial systems and practice, process designs and new marketing expertise) is organizationally embedded in the interdependent systems, expertise and complex individuals and groups' routines of the technology suppliers therefore these strategic valuable resources and competencies if transferred will lead to an increase the local firms' competitiveness, technological capabilities, organizational learning effectiveness, productivity and create potentials for innovations (Inkpen, 2000; Inkpen and Dinur, 1998; Xu, 2000; Liu and Wang, 2003). The results have expanded the general findings by Dhanaraj et al. (2004); where TCTDEG had a significant effect on IJV performance. The significant role of degree of explicit knowledge (EXPDEG) on human resource performance is explained by its explicit nature (manufacturing/service techniques/skills, promotion techniques/skills, distribution know-how, and purchasing know-how); which is frequently standardized by the technology supplier in the form of standard manuals, procedures, and blueprints thus it is less 'stickier' than tacit knowledge, easier to articulate and understand, and more easy to be shared, communicated and transferred.

Comparable to other formal market channels such as direct exporting of capital goods, foreign direct investments (FDIs), and licensing agreements, this study provides empirical evidence that the JVs formed between the foreign MNCs and local companies indeed have significant positive effects on performance of local companies. The results, however, contrary to a recent findings by Malairaja and Zawdie (2004); where their findings suggested that the TT through JVs in Malaysia have not succeeded in developing the indigenous innovation capabilities. This is particularly evident with the significant effect of degree of technology transfer (both TCTDEG and EXPDEG) on human resource performance. The significant effect of TCTDEG and EXPDEG on HRPERF in improving product quality and employees' productivity will positively boost local innovation capabilities when the local employees' absorptive capacity, which is based on the employees' prior related knowledge and intensity of effort, is capable of absorbing, assimilating, and improving new technologies extracted from JVs (Cohen and Levintahl, 1990; Kim, 1998). The results are consistent with the previous TT literature findings where substantial TT has positively led to a higher potential of innovation performance/capabilities (Guan et al., 2006; Kotabe et al., 2007), and increase the technological capabilities and competitiveness (Madanmohan et al., 2004; Liao and Hu, 2007; Rodriguez and Rodriguez, 2005). The results has further extended the KT literature, in particular the general findings by Minbeava (2007), Pak and Park (2004), and Hau and Evangelista (2007) on the overall significant effects of knowledge transfer and acquisition on JV's performance. Another critical finding of this study is that the main objective of the local companies participating in JVs was largely driven by their efforts to improve the product/service quality, employees' productivity, managerial techniques, and operational efficiency. The results in this respect support the findings by Lyles and Salk (1996) and Lane et al. (2001); where knowledge acquisition from foreign parent has significantly affected business and human resource performance. The results are also consistent with OL literature which views technology recipient organizations as a learning system and TT as an organizational learning process (Daghfous, 2004; Bapuji and Crossan, 2004).

One of the major limitations encountered by this study was the resource constraints; where this study has mainly relied on responses obtained from the top management level of the JVs. Thus, the scope of respondents could have been extended to include the response from the middle and lower management levels in the JVs. Secondly, consistent with the literature, the subjectivity of nature of relationship is difficult to capture. Thus, the nature of relationship between IJV partners could have tremendously affected the results if the respondents perceived that the IJVs were competitive in nature rather than collaborative. Thirdly, due to lack of awareness on academic research the response rate in terms of the number of usable questionnaires, though sufficient, was not encouraging. This has become a major challenge to many researchers who conduct organization studies in Malaysia. Finally, due to time constraints, the types of technology under investigation in this study were limited to tacit and explicit knowledge.

This empirical study is a response to the need for statistical evidence that has typically been lacking in inter-firm TT literature. Since this study focuses on degree of inter-firm TT, future studies could be conducted to further examine the effects of degree of technology transfer on level of innovation, competitiveness, productivity, and 
technological capabilities of local firms. The above relationship could also be extended to cover other formal inter-firm TT agents such as FDIs and licensing. Secondly, it is worthwhile to extend the tacit and explicit dimensions of technology to cover other dimensions of supply chain activities. Future studies may focus on the relationships and effects of degree of technology transfer on other dimensions of tacit and explicit technology/knowledge of supply chains such as production, marketing, management, and distribution. Thirdly, since the IJV literature has highlighted the high instability rate of IJVs in developing countries, future studies could be directed to empirically examine the relationships between degree of inter-firm TT and conflicts, learning outcomes, asymmetric bargaining power, stability of JV, and equity ownership. Finally, given the linear relationship between degree of technology transfer and local firms' performance, future studies could further investigate the effects of few established moderating variables such as organizational culture, collaborative know-how, prior JV experience, and learning capacity on the relationship to provide new insights and information on the boundary condition of the relationship.

\section{References}

Allen, D. R., \& Rao, T. R. (2000). Analysis of Customer Satisfaction Data. United States of America: America Society for Quality.

Bapuji, H., \& Crossan, M. (2004). From Questions to Answers: Reviewing Organizational Learning Research, Management Learning, 35(4), p. 397-417.

Blomstrom, M. (1990). Transnational Corporations and Manufacturing Exports from Developing Countries. New York, United Nations.

Bresman, H., Birkinshaw, J., \& Nobel, R. (1999). Knowledge Transfer in International Acquisitions. Journal of International Business Studies, 30(3), p. 439-62.

Caves, R.E. (1974). Multinational Firms, Competition and Productivity in Host-Country Markets. Economica, 41, p. 176-193.

Chen, E.K.Y. (1996). Transnational Corporations and Technology Transfer to Developing Countries in UNCTAD, Transnational Corporations and World Development, p. 181-214, London, UK: Thompson Business Press.

Chung, W. (2001). Identifying Technology Transfer in Foreign Direct Investment: Influence of Industry Conditions and Investing Firm Motives, Journal of International Business Studies, 32(2), p. 211-229.

Cohen, W. M., \& Levinthal, D.A. (1990). Absorptive Capacity: A New Perspective on Learning and Innovation, Administrative Science Quarterly, 35(1), p. 128-52.

Cui, A.S, Griffith, D.A., Casvugil, S.T., \& Dabic, M. (2006).The Influence of Market and Cultural Environmental Factors on Technology Transfer between Foreign MNCs and Local Subsidiaries: A Croatian Illustration. Journal of World Business, 41; p. 100-111.

Cumming, J.L., \& Teng, B.S. (2003). Transferring R\&D Knowledge: The Keys Factors Affecting Knowledge Transfer Success. Journal of Engineering and Technology Management, 20, p. 39-68.

Daghfous, A. (2004). An Empirical Investigation of the Roles of Prior Knowledge and Learning Activities in Technology Transfer. Technovation, 24, p. 939-953.

Dess, G. G., \& Robinson, R. B. J. (1984). Measuring Organizational Performance in the Absence of Objective Measures: The Case of the Privately-Held Firm and Conglomerate Business Unit, Strategic Management Journal, 5 (3), p. 265-73.

Dhanaraj, C., Lyles, M.A., Steensma, H.K., \& Tihanyi, L. (2004). Managing Tacit and Explicit Knowledge Transfer in IJVs: the Role of Relational Embeddedness and the Impact on Performance, Journal of International Business Studies, 35(5), p. 428-42.

Dierickx, I., \& Cool, K. (1989). Asset Stock Accumulation and Sustainability of Competitive Advantage. Management Science, 35, p. 1504-1541.

Dunning, J.H. (1993). Multinational Enterprise and the Global Economy. Reading, MA: Addison-Wesley.

Ernst, D., \& Kim, L. (2002). Global Production Network, Knowledge Diffusion, and Local Capability Formation. Research Policy, 31, p. 1417-1429.

Galbraith, J.K. (1972). The New Industrial State. London, UK: Andre Deutsch. 
Geppert, M., \& Clark, E. (2003). Knowledge and Learning in Transnational Ventures: An Actor-Centred Approach. Management Decision, 41(5), pp.433-442.

Geringer, J. M., \& Hebert, L. (1991). Measuring Performance of International Joint Ventures, Journal of International Business Studies, 22(2), p. 249 - 63.

Geringer, J.M. (1991). Strategic Determinants of Partner Selection Criteria in International Joint Ventures. Journal of International Business Studies, 22(1), $1^{\text {st }}$ Quarter, p. 41-62.

Glaister, K.W., Husan, R., \& Buckley, P.J. (2003). Learning to Manage International Joint Venture. International Business Review, 12(1), pp. 83-108.

Goulet, D. (1989). The Uncertain Promise: Value Conflicts in Technology Transfer. New York: New Horizons Press.

Grosse, R. (1996). International Technology Transfer in Services. Journal of International Business Studies, 27(4), p. 781-800.

Guan, J. C., Mok, C. K., Yam, C.M., \& Pun, K. F. (2006). Technology Transfer and Innovation Performance: Evidence from Chinese Firms. Technological Forecasting and Social Change, 73, p.666-678.

Gupta, A. K., \& Govindarajan, V. (2000). Knowledge Flows within Multinational Corporations. Strategic Management Journal, 21(4), p. 473-96.

Harrigan, K.R. (1984). Joint Ventures and Global Strategies. Columbia Journal of World Business, 19(2), p. $7-16$.

Hau, L. N., \& Evangelista, F. (2007). Acquiring Tacit and Explicit Markrting Knowledge from Foreign Partners in IJVs. Journal of Business Research, 60, pp. 1152-1165.

Hawthorne, E. P. (1971). The Transfer of Technology: Paris, OEDC.

Inkpen, A. C. (1998a). Learning and Knowledge Acquisition through International Strategic Alliances. The Academy of Management Executive, 12(4), p. 69-80.

Inkpen, A. C. (1998a). Learning and Knowledge Acquisition through International Strategic Alliances. The Academy of Management Executive, 12(4), p. 69-80.

Inkpen, A. C., \& Crossan, M.M (1995). Believing is seeing: Joint Ventures and Organizational Learning. Journal of Management Studies, 32(5), p. 596-618.

Inkpen, A. C., \& Currall, S.C. (2004). The Coevolution of Trust, Control, and Learning in Joint Ventures. Organization Science, 15(5), p. 586-99.

Inkpen, A.C. (2000). Learning through Joint Ventures: A Framework of Knowledge Acquisition. Journal of Management Studies, 37(7), p. 1019-1043.

Jones, R. (1970). The Role of Technology in the Theory of International Trade, in R. Vernon, (Eds.). The Technology Factors in International Trade, NewYork: Universities Bureau of Economics Research.

Kim, L. (1998). Crisis Construction and Organizational Learning: Capability Building in Catching-up at Hyundai Motor. Organization Science, 9(4), p. 506-521.

Kogut, B. (1988). Joint Ventures: Theoretical and Empirical Perspectives, Strategic Management Journal, 9(4), p. 319-32.

Kogut, B., \& Zander, U. (1992). Knowledge of the Firm, Combinative Capabilities, and the Replication of Technology. Organization Science, 3(3), 383-97.

Kogut, B., \& Zander, U. (1993). Knowledge of the Firm and the Evolutionary Theory of the Multinational Corporation. Journal of International Business Studies, 24(4), p. 625-646.

Kotabe, M., Dunlap-Hinkler, D., Parente, R., \& Mishra, H. (2007). Determinants of Cross-National Knowledge Transfer and Its Effect on Firm Innovation. Journal of International Business Studies, 38, p. $259-282$.

Kumar, V., Kumar, U., \& Persaud, A. (1999). Building Technological Capability through Importing Technology: The Case of Indonesian Manufacturing Industry. Journal of Technology Transfer. 24, p. 81-96.

Lado, A., \& Vozikis, G. (1996). Transfer of Technology to Promote Entrepreneurship in Developing Countries: An Integration and Proposed Framework. Entrepreneurship Theory and Practice, Winter, p. 55-72. 
Lai, Y.W., \& Narayanan, S. (1997). The Quest for Technological Competence via MNCs: A Malaysian Case Study. Asian Economic Journal, 11(4), p. 407-422.

Lam, A. (1997). Embedded Firms, Embedded Knowledge: Problems of Collaboration and Knowledge Transfer In Global Cooperative Venture, Organization Studies, 18(6), pp.973-996.

Lane, P. J., Salk, J.E., \& Lyles, M.A. (2001). Absorptive Capacity, Learning, and Performance in International Joint Ventures, Strategic Management Journal, 22(12), p. 1139-61.

Lee, H.H., \& Tan, H. B. (2006). Technology Transfer, FDI and Growth in the ASEAN Region. Journal of the Asia Pacific Economy, 11(4), p. 394-410.

Liao, S.H., \& Hu, T.C. (2007). Knowledge Transfer and Competitive Advantage on Environmental Uncertainty: An Empirical Study of the Taiwan's industry. Technovation, 27, p. 402-411.

Lin, W.B. (2003). Technology Transfer as Technological Learning: A Source of Competitive Advantage for Firms with limited R\&D Resources. $R \&$ D Management, 33(3), p. 327-341.

Lin, W.B. (2007). Factors Affecting the Correlation between Interactive Mechanisms of Strategic Alliance and Technological Knowledge Transfer Performance. The Journal of High Technology Management Research, 17, p. 139-155.

Lin, X. (2005). Local Partner Acquisition of Managerial Knowledge in International Joint Ventures: Focusing on Foreign Management Control. Management International Review, 45(2), p. 219-237.

Liu, S., \& Vince, R. (1999). The Cultural Context of Learning in International Joint Ventures. Journal of Management Development, 18 (8), p. 666-675.

Liu, X., \& Wang, C. (2003). Does Foreihn Direct Investment Facilitate Technological Progress? Evidence from Chinese Industries. Research Policy, 32, p. 954-953.

Lovell, S.A. (1998). Technology Transfer: Testing a Theoretical Model of the Human, Machine, Mission, Management and Medium Components. Unpublished Msc.thesis. Cranfield: College of Aeronautics, Cranfield University.

Luo, Y., \& Peng, M.W. (1999). Learning in a Transition Economy: Experience, Environment, and Performance, Journal of International Business Studies, 30(2), pp. 269-296.

Lyles, M. A., \& Barden, J. Q. (2000). Trust, Controls, Knowledge Acquisition from the Foreign Parents and Performance in Vietnamese IJVs. Submission to the International Management Division of the AOM meeting.

Lyles, M. A., \& Salk, J.E. (1996). Knowledge Acquisition from Foreign Parents in International Joint Ventures: An Empirical Examination in the Hungarian. Journal of International Business Studies, 29(2), p. 154-74.

Madanmohan, T.R., Kumar, U., \& Kumar, V. (2004). Import-led Technological Capability: A Comparative Analysis of Indian and Indonesian Manufacturing Firms. Technovation, p. 979-993.

Makhija, M.V., \& Ganesh, U. (1997). The Relationship between Control and Partner Learning-Related Joint Ventures. Organization Science, 8(5), p. 508-527.

Malairaja, C., \& Zawdie, G. (2004). The 'black box' Syndrome in Technology Transfer and the Challenge of Innovation in Developing Countries, International Journal of Technology Management and Sustainable Development 3(3), p. 233-251.

Markusen, J.R., \& Venables, A.J. (1999). Foreign Direct Investment as a Catalyst for Industrial Development. European Economic Review, 43, p.335-356.

Martin, X.Y.F., \& Salomon, R. (2003). Knowledge Transfer Capacity and its Implications for the Theory of the Multinational Corporation. Journal of International Business Studies, 34(4), 356-373.

Millman, A.F. (2001). Technology Transfer in the International Market. European Journal of Marketing, 17(1), p. 26-47.

Minbaeva, D. (2007). Knowledge Transfer in Multinationals, Management International Review, 47(4), p. 567-593.

Mowery, D.C., Oxley J.E., \& Silverman B.S. (1996). Strategic Alliances and Interfirm Knowledge Transfer. Strategic Management Journal, 17, p. 77-91.

Narayanan, S., \& Lai, Y. W. (2000). Technological Maturity and Development without Research: The Challenge for Malaysian Manufacturing. Development and Change, 31, p. 435-457. 
Nelson, R., \& Winter, S. (1982). An Evolutionary Theory of Economic Change. Harvard University Press: Cambridge, MA.

Nonaka, I. (1994). A Dynamic Theory of Organizational Knowledge Creation. Organization Science, 5, p. 14-37.

Ofer, C., \& Polterovich, V. (2000). Modern Economics Education in TEs: Transfer Technology in Russia. Comparative Economic Studies, 42(2), p. 5-35.

Pak, Y., \& Park, Y. (2004). A Framework of Knowledge Transfer in Cross-Border Joint Ventures: An Empirical Test of the Korean Context, Management International Review, 44(4), p. 435-455.

Polanyi, M. (1962). Personal Knowledge: Towards a Post-Critical Philosophy, Chicago: University of Chicago Press.

Polanyi, M. (1967). The Tacit Dimension. Anchor, Garden City, NY.

Reisman, A. (2005). Transfer of Technologies: A Cross-disciplinary Taxonomy. The International Journal of Management Science, 33, p. 189-202.

Rodriguez, J.L., \& Rodriguez, R.M.G. (2005). Technology and Export Behaviour: A Resource-Based View Approach. International Business Review, 14, p. 539-557.

Rozhan, O., Rahayu \& Rashidah. (2001). Great Expectation: CEO's Perception of the Performance Gap of the HRM functions in the Malaysian Manufacturing Sector. Personnel Review, 30 (1), 1\& 2, p. 61-80.

Sekaran, U. (2003). Research Methods for Business, Fourth Edition, John Wiley \& Sons, Inc.

Si, S. X., \& Bruton, G. D. (1999). Knowledge Transfer in International Joint Ventures in Transitional Economy: The China Experience. The Academy of Management Executive, 13(1), p. 83-90.

Simonin, B. L. (1999a). Ambiguity and the Process of Knowledge Transfer in Strategic Alliances. Strategic Management Journal, 20(7), p. 595-623.

Simonin, B. L. (2004). An Empirical Investigation of the Process of Knowledge Transfer in International Strategic Alliances. Journal of International Business Studies, 35(5), 407-27.

Simonin, B.L. (1999b). Transfer of Marketing Know-how in International Strategic Alliances: An Empirical Investigation of the Role and Antecedents of Knowledge Ambiguity. Journal of International Business Studies, 30(3) p. 463-90

Steensma, H. K., \& Lyles, M.A. (2000). Explaining IJV Survival in a Transitional Economy through Social Exchange and Knowledge-based perspectives. Strategic Management Journal, 21(8), p. 831-51.

Strassman, W.P. (1968). Technological Change and Economic Development: The Manufacturing Process of Mexico and Puerto Rico. Ithaca: Cornell University Press.

Techakanont, K., \& Terdudonthan, T. (2004), Evolution of Inter-firm Technology Transfer and Technological Capability Formation of Local Parts Firms in the Thai Automobile Industry. Journal of Technology Innovation, 12(2), p. 151-183.

Tepstra, V., \& David, K. (1985). The Cultural Environment of International Business, Cincinnati,, OH: Southwestern Publishing Co.

Tihanyi, L., \& Roath, A.S. (2002). Technology Transfer and Institutional Development in Central and Eastern Europe. Journal of World Business, 37, p. 188-198.

Tsang E.W.K., Tri D.N., \& Erramilli M.K. (2004). Knowledge Acquisition and Performance of International Joint Ventures in the Transition Economy of Vietnam. Journal of International Marketing, 12(2), p. 82-103.

Tsang E.W.K., Tri D.N., \& Erramilli M.K. (2004). Knowledge Acquisition and Performance of International Joint Ventures in the Transition Economy of Vietnam. Journal of International Marketing, 12(2), p. 82-103.

Tsang, E.W.K. (2001). Managerial Learning in Foreign-Invested Enterprises of China. Management International Review, 41 (1), 29-51.

von Hippel, E. (1994). Sticky Information and the Locus of Problem Solving: Implication for Innovation. Management Science, 40(4), p. 429-439.

Winter, S. (1987). Knowledge and Competence as Strategic Assets, in: Teece, D. (Eds.), The Competitive Challenge, Massachusetts, Cambridge: Ballinger Publishing Company. 
Wong, Y. Y., Maher, T. E., \& Luk, T. K. (2002). The Hesitant Transfer of Strategic Managerial Knowlegde to International Joint Ventures in China: Greater Willingness Seems Likely in the Future, Management Review News, 25(1), pp. 1-16.

Xu, B. (2000). Multinational Enterprises, Technology Diffusion, and Host Country Productivity Growth. Journal of Development Economics, 62, p. 477-493.

Yin, E., \& Bao, Y. (2006). The Acquisition of Tacit Knowledge in China: An Empirical Analysis of the 'Supplier-side Individual Level' and 'Recipient-side' Factors. Management International Review, 46(3), p. 327-348.

Zander, U., \& Kogut, B. (1995). Knowledge and the Speed of the Transfer and Imitation of Organizational Capabilities: An Empirical Test. Organization Science, 6(1), p. 76-92.

Table 1. Descriptive Statistics and Correlation Matrix.

\begin{tabular}{cccccc}
\hline Variable & Mean & SD & $\mathbf{1}$ & $\mathbf{2}$ & $\mathbf{3}$ \\
\hline TCTDEG & 5.72 & 1.74 & 1.000 & & 1.000 \\
EXPDEG & 5.91 & 1.45 & $0.747^{* * *}$ & $0.660^{* *}$ & 1.000 \\
CPERF & 6.47 & 1.34 & $0.597^{* *}$ & & \\
TCTDEG & 6.08 & 1.48 & 1.000 & $0.747^{* *}$ & 1.000 \\
EXPDEG & 5.91 & 1.45 & $0.639^{* *}$ & $0.740^{* *}$ & 1.000 \\
HRPERF & 6.47 & 1.34 & & & \\
\hline
\end{tabular}

$n=128, * p<0.05, * * p<0.01$

Table 2. Results of group Regression Analysis ${ }^{\mathrm{a}}$

\begin{tabular}{lll}
\hline Variable & $\begin{array}{l}\text { Corporate Performance } \\
(\text { Model 1) }\end{array}$ & $\begin{array}{l}\text { Human Resource Performance } \\
(\text { Model 2) }\end{array}$ \\
\hline (Constant) & $1.366^{* * *}$ & $8.804^{* * *}$ \\
TCTDEG & $0.485^{* * *}$ & $0.196^{*}$ \\
EXPDEG & $0.234^{* *}$ & $0.593 * * *$ \\
& & \\
$R$-Squared & 0.460 & 0.564 \\
Adjusted $R$-Squared & 0.452 & 0.557 \\
$F$ & $53.309 * * *$ & $80.836^{* * *}$ \\
\hline
\end{tabular}

${ }^{a}$ Cell entries are standardised coefficient estimates $(n=128)$

$\dagger p<0.10, * p<0.05, * * p<0.01, * * * p<0.001$ 